\title{
META-ENTITY (AL-GHAYR) AND ITS VALUE METAPHYSICS IN AL-MĀTURĪDī
}

\section{İbrahim Aslan}

\author{
Ankara University, Ankara-Turkey \\ iaslan@ankara.edu.tr \\ https://orcid.org/0000-0003-2182-9996
}

\begin{abstract}
This paper addresses the problem of value, which, despite its importance in the thought of divinity (al-ulübiyyah), is often overshadowed by the problem of being and knowledge. In particular, we will dwell on criticism by al-Māturīdī of Mu'tazilī conceptions of divinity based on intellectual and moral premises. The objective is to depict the establishment of unity between being/entity, knowledge and value in the system of al-Māturīiñ. In this regard, this study analyzes the concept of the meta-entity (الغير), which was apparently used for the first time by al-Māturīīi in kalām thought and terminology. In addition, we conduct an epistemic interpretation of the unity ensured between being/entity, knowledge, and value on the basis of the meta-entity to clarify the epistemic metaphysics of value that defends the being in itself of divinity against the ethical metaphysics of value established by Muctazilah in such a manner as to harm the transcendence of divinity.
\end{abstract}

Key Words: Meta-entity (الغير), divinity, value, reasoning/limmiyyah, being in itself/inniyyah, al-Māturīīi 


\section{Introduction}

Within the context of prophethood, religion comprises two-sided relationality, namely, vertical and horizontal. The former defines the expositional quality, meaning, evidence, and limits of religion, whereas the latter expresses how the expositional content of religion becomes subject to human thought and the main reference of truth and the true path. The intersection of these two aspects of religion leads to a dialectic between the depiction of divine statement (al$w a b y)$ and the conception of human intellect (al-'aql). This context enables an intellectual experience in which religion attains its final limits for the exposition of the mediation of various approaches to being, knowledge, and value. Within this unity, the crucial aspect of religious thinking is the comprehension of divinity as a value.

This paper aims to analyze the metaphysics of the value of divinity from the perspective of al-Imām al-Māturīdī (d. 333/944) and his criticisms of Mu'tazilah within an environment where kalām studies are overwhelmed by discussions about being and knowledge. There are numerous issues to highlight in this framework, but two of them are particularly worth noting. The first is that field studies excessively concentrate on contrasts, inevitably nourishing generalization and reduction. The second is that the genuine quests of high synthetic quality within kalām become unimportant within the sphere of influence of dominant discourses. In consideration of these two grounds, one can easily assert that al-Māturīdī has been subject to generalization/screening of Ahl al-sunnah, particularly regarding his views about the metaphysics of value.

In this respect, this paper aims to use a descriptive and comparative approach to demonstrate the conception of value by alMāturīdī, his reflections on divinity, and his criticisms about the essentialist and absolutist theory of the Muctazilah of Baghdad. In addition, this paper identifies his views that exceed the value conception of Ash'arī discourse into which he is drawn due to theological standardization and homogenization. In this respect, it is fair to indicate in advance that this study is limited to al-Māturīiñ and the intellectual spheres that he criticizes. Pursuant to this context, Kitāb al-tawhīd identifies three notable spheres of metaphysics: Naturalists, Dualists, and the Mu'tazilah.

Accordingly, it will be useful to touch upon the essentials of the intellectual dialectic that thrives in three directions, namely, progress, 
expansion, and deepening by means of revelation and which involves al-Māturīdī as well. This religious thinking, with the Qur'ān at its heart, can be analyzed pursuant to two fundamental aspects. The first is that Muslims have found themselves first side-by-side and then intertwined with an intellectual background that comprises various assertions of the region about religious and philosophical truth. The second is that this intellectual presence compels believers to conceive of the content of religion, described by the Qur'ān, regarding truth and the true path and an intellectual challenge. On the one hand, these two compelling conditions, which make each other meaningful, enabled the formation of theological, philosophical, and Sufi thought as different forms of conceptualization; on the other hand, they allowed for the expansion and diversification of three basic ways of thinking about Islamic metaphysics. As a result, a process of internal criticism emerged between each manner of thinking; these interacted, ensuring an equivalent process of synthesis/fermentation. This intellectual process, which was formed by advancing from simple to complex, inevitably accompanied the process of internal criticism since it includes different perspectives and perceptions of importance. ${ }^{1}$ This process was systematized in Transoxiana; al-Māturīdī aimed at the Mu'tazilah school, which brought itself into being via external criticism. ${ }^{2}$ Al-Māturīdī proposed his views through his criticisms about the allegations of Muhammad ibn Shabīb (d. $3^{\text {rd }}$ century AH $/ 9^{\text {th }}$

1 The evolution of thought into internal criticism is historically based on practical issues that generate theological discourses as well as debates on truth and the true path triggered by them. Therefore, one may assert that the dynamics that propose the perspective of kalām are initially the first step in the transformation of religion into envisagement. Over time, they achieved an interaction resulting synthesis/fermentation primarily through philosophical endeavors and eventually through Sufi tendencies towards the abovementioned two factors, which were decisive in the formation conditions of the religion. Historical data that shed light on this era show that this experience of interaction between Islamic discourse and envisagement linked kalām, philosophy, and Sufism most commonly within Ash'ari discourse of the $11^{\text {th }}$ century. This new state of affairs evidently produced, in the broadest sense, discussions about being, knowledge, and value subject to common interest within religious thinking with divinity at the center.

2 Ulrich Rudolph, al-Māturìdi and the Development of Sunnì Theology in Samarqand, trans. Rodrigo Adem (Leiden \& Boston: Brill, 2015), 148 ff., https://doi.org/10.1163/9789004261846. 
century $\mathrm{AD}$ ), who, despite being mentioned within the Basrah tradition, apparently broke away from the conventional approach of this school, as well as opinions of the contemporaneous thinker Abū 1-Qāsim al-Balkhī (d. 319/931). ${ }^{3}$ Presumably, this approach by alMāturīīi was a necessity rather than a preference. Indeed, since he did not leave the Samarqand region and the surrounding intellectual sphere, he was deprived of the possibility of being familiar with the literature during the organization process of the Muctazilah. Nevertheless, making use of intellectual and theological possibilities provided by his region, ${ }^{4}$ al-Māturīdī undertook an indirect theological

3 In Kitāb al-tawḥ̂̀d, al-Māturīdī mentions Abū l-Qāsim al-Balkhī as "al-Ka'bī," underlining that al-Balkhī is known among his followers as the "imām of everyone." According to tabaqāt literature, Muhammad ibn Shabỉb lived in the mid- $3^{\text {rd }}$ century; as a kalām scholar in the tradition of al-Naẓāam, he was famous for his work on tawhīd. On the other hand, al-Ka'bī was criticized by his environment for his views in defense of pushing back of judgment (al-irjā ). He is considered among the seventh generation of the Mu'tazilah tradition. See Abū 1-Qāsim 'Abd Allāh ibn Aḥmad al-Balkhī, Kitāb al-maqālāt wa-ma'ahū 'Uyūn almasā'il wa-l-jawābāt, ed. Hüseyin Hansu, Rājị̣ Kurdī, and 'Abd al-Hamīd Kurdī (Istanbul: KURAMER, 2018), 201; Abū 1-Hasan 'Alī ibn Ismācīl al-Ash`arī, Maqālāt al-Islāmiyyīn wa-khtilāf al-muṣallīn, ed. Aḥmad Jād (Cairo: Dār al-Hadìth, 2009), 201; Abū Manșūr 'Abd al-Qāhir ibn Ṭāhir al-Baghdādī, al-Farq bayna l-firaq wabayān al-firqah al-nājiyah minhum: 'Aqā'id al-firaq al-Islāmiyyah wa-ārā' kibār a lāmihā, ed. Muhammad 'Uthmān al-Khusht (Cairo: Maktabat Ibn Sīnā, 1988), 25, 207; Abū l-Ḥasan al-Qāẹī 'Abd al-Jabbār ibn Aḥmad al-Hamadānī, Faḍl al-i'tizāl wa-țabaqāt al-Mu'tazilah, ed. Fu’ād Sayyid (in Faḍl al-i'tizāl wațabaqāt al-Mu'tazilah, along with Abū l-Qāsim al-Balkhī's (Bāb) Dhikr alMu'tazilah min Maqālāt al-Islāmiyyīn and Ḥākim al-Jishumī's al-Ṭabaqatān albāadiyah 'ashrab wa-l-thāniyah 'ashrah min kitāb Sharh al-cuyūn, Tunis: al-Dār al-Tūnisiyyah li-l-Nashr, 1974), 74, 279; Abū l-Fath Tāj al-Dīn Muhammad ibn 'Abd al-Karīm al-Shahrastānī, al-Milal wa-l-niḥal, ed. Aḥmad Fahmī Muhammad (Beirut: Dār al-Kutub al-'Ilmiyyah, 1990), I, 86, 259, 267.

4 Abū Manṣūr Muḥammad ibn Muḥammad ibn Maḥmūd al-Māturīdī, Kitāb altawhīd, ed. Bekir Topaloğlu and Muhammed Aruçi (Beirut \& Istanbul: Dār Ṣādir \& İSAM Yayınlar1, 2007), 191-193, 202, 238. For instance, the author notes replies by Muhammad ibn Shabīb to the Dahriyyah, Mulhids, and Thanawiyyah to start a discussion. 
confrontation with Mu'tazilī discourse. ${ }^{5}$ Indeed, the content, intellectual texture, and pattern of Kitāb al-tawhìd provides the strongest evidence of his approach. Within this context, al-Māturīiñ becomes even more interesting since he established a relation of interaction and assimilation between views of internal and external respondents whom he targeted and criticized. His point of view can be considered as a two-way and complementary perspective that moves from within to outside dialectics or from outside into it under equal circumstances.

\section{From Entity to Meta-Entity (الغير)}

Al-Māturīdi presents his approach to the metaphysics of value, addressing Mu'tazilah and the Mu'tazili thought. This is closely related to the fact that the Mu'tazilah is the main theological movement that took the truth value and true path quality of religion to the realm of thought for the first time and criticized other

5 In this regard, the content of Kitāb al-tawhì d deserves analysis in both contexts. In terms of opposition to the Mu'tazilah, the fundamental matters of debate are mostly classical themes, such as the problem of tawhid, the essence and attributes of Allah, the problem of nonexistence, the questionability of the origin of elements related to creation, unbearable obligation (taklīf mā la $y u t a \bar{q} q$ ), the wisdom of order and negation, the wisdom behind the creation of harmful beings, divine decree and predestination (al-qada $\bar{a}^{\prime} w a-l$-qadar), will, the great sin, and discussions on faith. Moreover, Kitāb al-tawhīd comprises a chapter where a satirical narrative that likens qadariyyah, one of the contexts that excessively crystalizes opposition against Muctazilah, to Zoroastrianism. This context, which serves disreputation among Ash`arī and Salafī circles, is addressed in the work by al-Māturīīi as a theme of interaction through his detailed findings and analyses.

6 I have two grounds for my English translation of the concept of al-ghayr (الغير), which has a central role in al-Māturīdī's thought about divinity. The first is that the author used this concept in explaining that the universe cannot be explained through and by itself; the second is his assertion that this concept is explicit intellectual evidence of the universe. When these two issues are considered together, the concept of al-ghayr, namely, meta-entity, corresponds to a kind of signification that is outside the universe that is categorically distinct to it. For me, "meta" is the best available word to stress this fact. Given its different associations and use by authors to identify a being outside and distinguished from the universe, I attempt to clarify the concept with the wording "meta-entity." 
allegations of religion and truth. Accordingly, as the content of Kitāb al-tawhì shows, the approach by al-Māturīin towards the metaphysics of value cannot be appropriately comprehended unless the Mu'tazili approach is taken into account. Therefore, it would be useful to briefly touch upon the Mu'tazili point of view.

As is known, the Mu'tazilah represents religious thinking that prioritizes intellect over divine statement (al-waby). This attitude, closely related to the perspective of knowledge and value, defends the unity of truth against naturalist, materialist and dualist allegations, ${ }^{7}$ which are also criticized by al-Māturīiñ. Within this methodology, religion turns into a thought in compliance with intellect and morality. For this approach, intellect is indispensable for being-truth, meaning, and validity in human thinking, whereas morality is the only reference that may ensure meaning and validity for the value and the binding quality of religion. In this respect, religion is nothing but putting the intellectual and moral to the mediation of divine statement (al-wahy). ${ }^{8}$

Al-Māturīin was a pioneer and sharer of anti-Mu'tazilah discourses, which tried to reinforce the authority of the divine against the unity of truth. Therefore, in the anti-Mu'tazilah approach, divinity underwent division in terms of existence, cognition, and value, and religion is taken to a ground that exceeds (or can exceed) the intelligible or

I mean here Thanawī and Majūsī theological circles that are based on the thought of dualism. For this reason, I prefer to use the concept of dualists for both on the following pages.

8 Al-Qāọī 'Abd al-Jabbār considers intellect and morality as two nested principles of the legitimacy and intelligibility of religion; as he discusses the meaning and implication of the names attributed to Allah, he grounds this discussion on the principle that "meaning cannot vary depending on the visible (al-shähid) and the unseen $\left(a l-g h \bar{a}^{\prime} i b\right)$. . In this respect, he criticizes the transcendentalist attitude that wants to attain differentiation of meaning and implication in both fields (al-Qādì 'Abd al-Jabbār, al-Mughnī fì abwāb al-tawhīd wa-l-'adl, V [al-Firaq ghayr alIslāmiyyah], ed. Maḥmūd Muḥammad Qāsim [Cairo: al-Dār al-Miṣriyyah li-l-Ta'līf wa-1-Tarjamah, n.d.], 184). He crystallizes this view in a strict manner with the statement, "The truth of qualities/predications/judgments can never change or differ depending on differentiation of apparent and unseen realms." Ibid., 205; cf. al-Mughnī, XIV (al-Așlaḥ, istiḥqāq al-dhamm, al-tawbah), ed. Mușțafá al-Saqqā (Cairo: al-Dār al-Mișriyyah li-1-Ta'līf wa-l-Tarjamah, 1965), 13. 
ethical in an absolute or relative manner with its relation to divinity. Consequently, the unity and transitivity of indication between intellect, morals, and religion were subject to negative affection. In this regard, we may take a closer look at criticisms by al-Māturīiñ about Mu'tazili discourse, which unifies truth on the basis of intellect and ethics and thus unifies the divine and human realms in terms of indication and value. As we will explain in the following pages, alMāturīdī divided his criticisms about the human and divine realms and explained this through the principle of being in itself/selfhood (al-inniyyab). It seems useful to emphasize the fundamental determinants of Mu'tazili discourse for an appropriate and correct comprehension of al-Māturīdī's criticisms.

The Mu'tazilah is widely known as a school of thought that is almost completely grounded on intellect in its approach to being, knowledge, and value; nevertheless, this judgment/perception is principally groundless and incorrect. The writings of al-Qādī 'Abd alJabbār (d. 415/1025), the strongest reference of extant Mu'tazili literature, show that the mentioned discourse ascribes a value not only to intellect but also to ethics and language in an equivalent manner. The center of gravity of this three-value perspective of importance, which was particularly formed in the Mu'tazilah of Basrah, has varied depending on the characteristics of the relevant subject matter. ${ }^{9}$ In this context, the Mu'tazilah is grounded on categorical ethical premises which, according to the Mu'tazili claim, served as the origin of problems with regard to the value theory of

9 The Mu'tazilī perspective adopts an attitude principally based on intellect and logic about the problem of nonexistence ( $a l-m a^{\prime} d \bar{u} m$ ), an attitude based on unity of comprehension (al-idrāk) and intellect ( $a l^{\prime}$ ' $\left.a q l\right)$ in discussions of the essence of the universe, and displays a pattern acting on the unity of language, ethics, and intellect pursuant to the nature of the problem in regard to the essence of the Qur'ān. The Mu'tazilī conception of knowledge explains the cognition of intellect as universal and qualitative and the cognition of divine statement (al-waby) as conditional/contextual (al-tafșì $\bar{l}$ ). In addition, the Mu'tazilah wants to build the jurisprudent, binding aspect of the Qur'ān on ethical principles such as good, evil, obligatory (al-wäjib), benefit (al-mașlahah), and harm (al-mafsadah), which are also regulatory principles of the realm of activity. See İbrahim Aslan, Kâdî Abdülcebbâr'a Göre Dinin Aklî ve Ablâkî Savunusu (Ankara: OTTO Yayınları, 2014), $293 \mathrm{ff}$. 
divinity. The Mu'tazilah school was convinced that the good/evil within human reality should also be good/evil in the realm of divinity. Accordingly, the Mu'tazili school tried to develop a universal theory of value to involve both human and divine realms, asserting that the change of realms of existence and knowledge will not alter the truth.

Pursuant to this point of view, the ontological contrast between the creator and the created cannot be made a justification and means of legitimacy for a theory of transcendent value. It is possible to think that there are two principle reasons for the distinction between the aspect of value and existential and epistemological aspects; these two reasons can be described as "the existential and epistemological aspects are related to the quiddity of divinity" and "the aspect of value is mostly about relationality with the other." Value cannot be constructed as a theory peculiar to the divine realm and the transcendent because of its aspect that includes relationality with others as much as itself. Otherwise, this would mean breaking off from the ground of legitimacy both the nature of Allah, which is treated as divine exposition, and the quality of religion that is binding on man (al-shari $\left.{ }^{c} a b\right)$. In consideration of these two justifications, the Mu'tazilah argues that value has an internal, common, and involving unity in relation to the nature of the creator and the created and develops two different theories, one contextual and one absolutist. The contextual theory was defended by the Mu'tazilah of Basrah, whereas the absolutist theory was adopted by kalām scholars in the Baghdad region as an essentialist and perfectionist tendency. As a Mu'tazili theologian and member of the Basrah tradition, 'Abd alJabbār treats the theory of value at two levels, one as universal categories ( ușūl al-adillah and jumlat ${ }^{a n}$ ) applicable to all possibilities of realization within the human mind and the other as conditional/contextual (tafșì $\bar{\imath}$ ) depending on the qualities of things as well as the possibility and consequences of their realization. Accordingly, categorical knowledge (ușūl al-adillah) such as good, evil, justice, persecution, lie, righteousness, and absurdity take from 
themselves (inni) the necessary, explicit validity/causality of value judgments that do not require causation $\left(\operatorname{ta}^{\prime} l \bar{l} l\right){ }^{10}$

Such categorical knowledge constitutes the theory of value not only for human reality but also for divinity. These objective and constant value judgments involve any becoming, situation, will, and act related to creation as well as any act, situation, and becoming based on human will. In this regard, this theory of value, which unites the divine and human realms and is essentially ethical, is thought to have a single condition. According to this condition, the true criterion of the value of a thing is the conditions of its realization and the consequences it causes. Pursuant to this attitude, the relation between value judgment and act/becoming and situation is based on the movement/dynamism of being or existence. Therefore, an act does not obtain its value judgment from divine will, as Ash'arī discourse argues, or from divine knowledge, as will be explained in the following pages. In contrast, Mu'tazilah argues that value judgment should be sought in the self of a thing, which is related to judgment and the consequences that originate from such a thing. Therefore, in the realm of things, value is based on the manner and consequences of realization. ${ }^{11}$ As one of the scholars to bring this ethical theory to perfection, 'Abd al-Jabbār adhered to a positivist and dynamic attitude and asserted that the value judgment is dependent on the principle of movement and change of things. Thus, he criticized the Ash'arī approach that associates the value with divine will as well as the Mu'tazilah of Baghdad for their absolutist and essentialist view.

The absolutist theory, in turn, was developed by Mu'tazilì kalām scholars raised within the Baghdad tradition. The theory, also known as the best/optimum (al-așlaḥ), is based on the principle of perfection

10 Al-Qāḍī 'Abd al-Jabbār, al-Mughnī, XII (al-Naẓar wa-l-ma'ārif), ed. Ibrāhīm Madkūr (Cairo: al-Mu’assasah al-Miṣriyyah al-'Āmmah li-l-Ta'lif wa-l-Tarjamah wa-l-Ṭibā'ah wa-l-Nashr, n.d.), 138-139.

11 Al-Qāḍ̄̄ 'Abd al-Jabbār, al-Mughnī, VI/1 (al-Ta'dīl wa-l-tajwīr), ed. Aḥmad Fu’ād al-Ahwānī (Cairo: al-Mu’assasah al-Mișriyyah al-Āmmah li-l-Ta’lîf wa-l-Tarjamah wa-1-Ṭibā'ah wa-l-Nashr, 1962), 3, 41, 61, 66, 68; VII (Khalq al-Qur’ān), ed. Ibrāhīm al-Abyārī (Cairo: al-Sharīkah al-`Arabiyyah li-l-Ṭibā'ah wa-l-Nashr, 1961), 10, 50; XI (al-Taklīf), ed. M. 'Alī al-Najjār and 'Abd al-Halīm al-Najjār (Cairo: alDār al-Mișriyyah li-1-Ta’lif wa-l-Tarjamah, 1965), 4, 5, 84, 86. 
through a deductive perspective. The definition of Allah as absolute, perfect, and the best being by nature produced a determinist approach to cosmology and ethics, as in Mashshā'ī philosophy. In this regard, the universe is laden with value and has the best form of existence. According to this theory, to be the best not only explains existence but also includes a claim of necessity, namely, Allah has to do what is best and cannot do evil. ${ }^{12}$ Both of these views - this "absolutist, essentialist and determinist" theory of the Mu'tazilah of Baghdad and the theory of "aspects" (wujūh) by the Mu'tazilah of Basrah that imposes value judgments on things pursuant to the forms and consequences of their realization (right-wrong, benefit-harm) and that defines existence as dynamic in a conditional and contextual sense while defining value categories as universal - analyze human and divine acts within the same value system-more precisely, the ground of value judgments brought innately by the intellect.

In the face of the foregoing discourse, al-Māturīiñ proposed his own approach to value. He started with the condition that the unity between knowledge and value shall not be distorted in the realm of divinity. ${ }^{13}$ For him, ethics-based divinity is the most prominent thought that distorts such unity. Accordingly, he criticizes Mu'tazili value theory that claims the truth cannot be consistent without transitivity of indication between intellect and religion and developed a genuine perspective that addresses divinity and value theory on an epistemological basis, namely, in relation to divine knowledge, for the first time ${ }^{14}$ in kalām studies. Indeed, this attitude

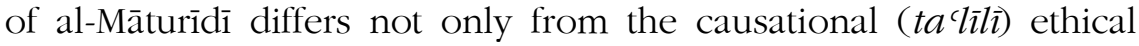
approach of the Mu'tazilah but also from the Ash'arī approach that explains divinity exclusively through divine will without attempting

12 Abū l-Husayn 'Abd al-Rahīm ibn Muhammad ibn 'Uthmān al-Khayyāṭ, Kitāb alintiṣār wa-l-radd 'alá Ibn al-Rāwandī al-mulḥid mā qașada bi-hī min al-kadhib 'alá-l-Muslimìn wa-l-ța'n 'alayhim, ed. Samuel Nyberg (Cairo: Maṭba'at Dār alKutub al-Mișriyyah, 1925), 17; Qāẹī 'Abd al-Jabbār, al-Mughnī, XIV, 13.

13 Aslan, “İmam Maturidî’nin Deist Eleştirilere Karşı Nübüvvet Savunusu," Kelâm Araştırmalar 12, no. 2 (2014), 9 ff., https://doi.org/10.18317/kader.03592.

14 It is worth noting that I attained this conviction through chronological comparison of extant kalām literature and the structural development of debates on divinity. If we reverse the view, this approach by al-Māturīdī never came to the agenda of Salafī circles or Ash`arì kalām scholars. 
any causational judgment. Within this equation, al-Māturīdī initially tries to determine that there is not only a difference but also a contrast of quiddity between the universe, which involves man as well, and divinity. ${ }^{15}$ Pursuant to his approach, value should change depending on being and its quiddity. Accordingly, for al-Māturīdī, it is impossible to advocate a common value theory for those whose quiddities are different and opposite. Indeed, opposition/contrast divides being, knowledge, and value; such dissociation considers being on two sides.

Grounded on this argument, al-Māturīdī asserts that one whose being and knowledge are transcendent should also be transcendent in terms of value, a view in agreement with the Muctazilah. He also argues that it is impossible for ethics to employ a metaphysics that includes divinity. Consequently, the motive that prevents ethics from exceeding the limits of physics is the existential, cognitive, and therefore value-related opposition between the realm of divinity and the universe.

Such opposition in compliance with the cognitive limits of man led to the division of being and made it intransitive in terms of value. Apparently, this division and intransitivity provided al-Māturīiñ with a point of origin that draws a line ${ }^{16}$ between physics and beyond and enables the determination of the essential, self-appellant quality of a thing. This situation surpasses ontological opposition and blocks the

15 The author articulates his point of view with the following eloquent statement: "The universe, whose nature is opposition (al-tanaffur), cannot be the reason for being of itself. Each thing is in reciprocal requirement of another thing. This is how it is extant and permanent. To be in itself means to have the quality of perpetuity itself; that is, to maintain presence without change under the same condition." See al-Māturīdī, Kitāa al-tawḥ̄d, 84. A similar argument is used by Ibrāhīm al-Naz̧āām, as seen from al-Khayyāț; cf. al-Khayyāț, Kitāb al-intiṣār, 44.

16 The line or limit is expressed in the most explicit and powerful manner as follows: “... Each of our senses is created so as to grasp what it is meant to. Presumably because of insufficiency of its self-involvement, another sense intervenes in order to ensure involvement. The same applies for intellect. Indeed, even though intellect is the possibility to know if what is apparently good and regular is really evil and irregular, it is something created that does (can) not exceed limits stipulated for it." See al-Māturīdī, Kitāb al-tawḥ̂̀d, 183. Also see 221 and 235 . 
quest for a value theory that involves both realms. Accordingly, alMāturīdī brings into question all assertions that corrode, expand, or restrict explicit limits of being, knowledge, and value. In this respect, al-Māturīīi aims for an ontological determination that enables criticism of both the Mu'tazili discourse and dualist theology.

To describe the two sides of being, al-Māturīin does not ground his argument on an approach that makes physics and metaphysics necessary components (al-illah wa-l-ma'lül) of one another, as in the theory of emanation by al-Fārābī (d. 339/950) and Ibn Sīnā (d. 428/1037), and he does not employ the typical theory of the atom used by the kalām tradition, although he is a shareholder of the latter. In fact, al-Māturīdī grounds his argument on a pair of concepts, universe/concrete (al-'ālam/al-a'yān] and meta-entity (al-ghayr) in regard to theology. The concept of al-ghayr, which we translate as meta-entity, ${ }^{17}$ expresses a perspective opposite the perspective that explains nature and physical reality with itself and attributes preeternalness to it. In Kitāb al-tawhìd, al-Māturīdī uses this concept to criticize philosophies and theologies that explain the universe by itself (naturalists [Tabī'iyyūn], dualists and Dabriyyūn) as well as the Mu'tazili envisagement of the universe and theory of creation that considers divine will within actual attributes and ascribes thingness to the nonexistent. In both contexts, the meta-entity is explained through a realist and rationalist approach that addresses the universe on the basis of apprehension and aims to grasp it in relation to becoming, changes, similitudes, contrasts, and differences in its nature, contrary to philosophical comprehension, which attributes causality and necessity (pre-eternalness) to the nature of the universe via categories of intellect. Therefore, the point of origin of the concept and principle called the meta-entity is that the universe is not the subject of itself and cannot be explained by itself but has an ontological validity that cannot be considered otherwise. If it were thought otherwise, this would lead to a paradox regarding arbitration within the coming of the universe into existence and remove the

17 This concept brings a meaning and definition that, semantically, both appeals and absolves something from things other than itself. The concept of al-ghayr, which establishes two mentioned points in a much more powerful manner than theological and philosophical circles, provides a genuine and significant indication in terms of not only being but also theory of knowledge and value. 
ontological opposition and distance between the universe and the meta-entity that explains its coming into existence.

Al-Māturīdī grounds his argument on a series of conceptual schemes that characterize the universe, in other words, on existence (al-kawn, al-mawjūd) within the cognitive limits of man and not on the philosophical notion of the existent (al-wujūd) through an abstraction to include everything. According to al-Māturīdī, even though al-'älam/al-acyān is a unity/entity that includes contrasts, similitudes, and differences by nature, it is within a becoming ( $\mathrm{al}$ kawn/al-b̧udūth), change (al-taghayyur), ${ }^{18}$ discontinuity (al-fana $\left.\bar{a}^{\prime}\right)$, transformation (al-inqilāb), and extinction (al-zawāl). Thanks to this manner of existence, the universe provides a foundation for a metaentity (al-ghayr) that can be exclusively understood and explained by means of the evidential order of intellect. Indeed, as is explicitly grasped, the universe has a compound nature consisting of parts and pieces. The subsequence of these pieces that constitute the whole is experienced in a direct and explicit manner in relation to processes of development, extension, and growth within the human capacity to grasp. Everything in the universe has the same quiddity since most things are so. Indeed, one cannot attain a conclusion of infinity upon the unification of parts that are found to be finite by experience. ${ }^{19}$ Moreover, infinity cannot be thought together with the manner of becoming/forming things. Contrasts such as clean-dirty, small-big, good-evil, and light-dark show the invalidity of such a claim. Therefore, the structure of the universe, which is based on change, cannot be thought together with the allegation that things can be explained by themselves. In contrast, this lays the foundation for extinction (al-halāk). Indeed, as experience shows, it points out unification $(a l-i j t i m \bar{a})$ and fragmentation (al-nashr) within things. Consequently, the assertion that "beings have a quiddity which

18 Al-Māturīīi indicates that the change in being, which he sees as taghayyur, is expressed in reference to various terminologies and states that some circles express this change as 'arad, whereas others employ the concept of sifah for it. See Kitāb al-tawhịd, 80.

19 In his explanation of the finitude of the universe in this context, the author argues that it is impossible to approach the universe with evidence not based on comprehension; al-Māturīdī refuses the claim that "things persist in existence even if they go out of sight." See al-Māturīìi, Kitāb al-tawḥ̄d, 78. 
cannot be perceived through senses and which does not blend with nihility" is groundless; therefore, it would be null and void to consider the universe with irrelevant concepts and evidence on nonintellectual grounds. ${ }^{20}$

Nothing in the universe exists by itself or unifies by itself $(i j t i m \bar{a}$ ). This arbitration in the world of objects can only and exclusively be possible with the meta-entity. The intellect is the most explicit and powerful evidence of this. ${ }^{21}$ Al-Māturīdī fortifies this view by means of his reply to the question of why things in the universe exist in a certain time in a certain condition and quality. Given all possibilities, the temporal, conditional, and qualitative changes show that being cannot be explained by itself. Therefore, the idea of bringing oneself to existence requires everything to bring itself into existence in the best-possible (ạsan) condition with the best-possible quality and value. Such an intellectual conclusion means the existence of a universe that does not comply with the actual and where there is no evil or malignity. ${ }^{22}$ In his criticism of the notion of bringing oneself into existence, the author argues that the thing is deprived of consciousness and awareness of itself. As proven by experience, the nonliving has no consciousness, and something devoid of consciousness cannot be the cause of its existence. The same applies to the living. Just like the nonliving, living things are in complete ignorance $(a l-j a b l)$ at the beginning of their existence. Therefore, they are incapable of existing/constructing themselves or similar things or even of improving their irregular aspects, even when they are powerful and competent. The living existences are unable in any case. Such a becoming shows that a thing comes into existence and undergoes a process of becoming by means of something outside it and by means of the meta-entity. Indeed, the universe cannot come into existence or undergo different, similar, and opposite manners without the meta-entity. ${ }^{23}$

Establishing the relation between the universe and the meta-entity through a basically rational approach, al-Māturīdī explains the perpetuity (al-baqa $\left.\bar{a}^{\prime}\right)$ of nonliving-living things in conditions such as

\footnotetext{
20 al-Māturīīi, Kitāb al-tawḥìd, 78.

21 Ibid., 82-83.

22 Ibid., 83.

23 Ibid., 83-84.
} 
movement and stillness through the benefit (manäfic al-ghayr) ${ }^{24}$ provided and the requirements (hawā'ij al-ghayr) ${ }^{25}$ fulfilled by objects for one another. His manner of comprehension shows that alMâturīdi agrees that the perpetuity within the unity of the universe cannot be considered pre-eternalness as well as the idea of a nonabsolute perpetuity and ordinance in the universe. ${ }^{26}$ According to the author, in the universe as a compound entity consisting of parts, everything follows each other $\left(a l-t a^{\prime} \bar{a} q u b\right)^{27}$ and generates benefit (al-manäfic) for the living. Within this correlation and reciprocity, each thing gathers around a single meaning. ${ }^{28}$

The author uses the examples of sperm and man to criticize the ontology that explains change in the universe with the transition of things from potential to actual. In the process of existence, the relation between sperm and the actual man shows not that these two things are the same but that they are two successive phases of the process of "becoming." For al-Māturīdī, the same correlation applies for the connection between a seed and a tree. ${ }^{29}$ Indeed, it is impossible that a thing emerges in itself as potentiality, emerges by folding in itself, or emerges through addition. Therefore, such potentiality/quwwah cannot be considered identical to the thing itself. The author clarifies his argument by means of correlation between sperm and man and seed and tree. For al-Māturīìi, both examples express the processes/states of becoming, development, and progress $(a b w \bar{a} l)$ of a thing in itself from the first to the final

\footnotetext{
24 Al-Māturīì̄, Kitāb al-tawḥ̂̀d, 78.

25 Ibid., 79.

26 Ibid., 79.

27 Ibid., 193. On another occasion, al-Māturīì̄ writes as follows: "Even though intellect grasps effects (al-'awāqib), it cannot know those beyond the limits of intellect, namely, the origins without effects." Ibid., 235. Pursuant to this distinction, according to the author, even though intellect may know, through the mediation of al-'awāqib, the wisdom behind the creation of things that include harm-benefit, it cannot know the final wisdom behind the creation of the universe since it has no 'awāqib.

Ibid., 83, 88.

29 Ibid., 79.
} 
stage. In this regard, no phase within the development and change of a thing is identical with another phase. ${ }^{30}$

Al-Māturīdī often repeats his allegation of interaction and similitude between the Mu'tazilah and the circles that he criticizes for their discourse. According to him, the Mu'tazilī cosmology shares a common ground with a naturalist and materialist approach that sees the universe as the subject of itself. His assertion is grounded on the Mu'tazili view of the problem of nonexistence, the attitude that attributes divine will and creation to the knowledge of Allah and does not provide Allah with a special position above the entire universe, as well as the perspective that considers divine will in the same quiddity as the universe as a divine attribute. ${ }^{31}$ The (transcendent) attribute of will, which should be directly ascribed to Allah, is ascribed to the universe, whereupon Allah is no longer the author of the universe ${ }^{32}$ and the allegations by other circles about the pre-eternity of the universe are indirectly approved. ${ }^{33}$

The foregoing discussions by al-Māturīdī about the universe confirm in a powerful manner the conviction that he cannot make way for his genuine perspective without criticizing the assertions of dualist philosophies and theologies that argue for the pre-eternity of the universe and the Mu'tazili cosmology that attributes thingness to the nonexistent (shay'iyyat al-ma'düm). This awareness further deepens the process of the transportation of theological problems to a cosmological ground.

\section{Al-Māturīìi, Kitāb al-tawḥ̂̀, 78.}

31 As al-Māturīdī proposes, divine will is defined not as an attribute present in Allah but as an attribute within the created act. Cf. al-Balkhī, Kitāb al-maqālāt, 255-258; also see Taqī al-Dīn Mukhtār ibn Maḥmūd al-'Ujālī al-Najrānī, al-Kāmil fì l-istiqșā' fìmā balaghanā min kalām al-qudamā', ed. Sayyid Muḥammad al-Shāhid (Cairo: Wizārat al-Awqāf, 1999), 285.

32 Al-Māturīìi, Kitāb al-tawhìd, 187. The point here, which is given as the relation of will to the universe, is not used by the Mu'tazilah in the sense that universe is the willer of itself. What is criticized here is the Mu'tazili consideration of the attribute of will among the category of the attributes of action. This category includes attributes that can be ascribed to Allah together with their opposite - to give/take life, to bestow/not bestow food, to have mercy/wrath, to speak/not to speak, to display/not display will, etc.

33 Ibid., 80. 
For him, there is no affirmative connection between the nonexistent and thingness (hastiyyah). ${ }^{34}$ Indeed, nonexistence means not to come (be brought) into existence yet. Even in temporal terms, it is impossible to describe as a "thing" what is "yet" to exist. Moreover, such a description cannot be considered together with the limit and distinction between the existent (al-mawjūd) and nonexistent (al-ma'dum). Nonexistence here corresponds with nothingness regardless of whether it is used as the possible (almumkināt) or the impossible (al-mustaḅilāt). Indeed, existence means to come from nothingness to being through creation. Therefore, the Muctazili theory of nonexistence ambiguates attributions of existence such as time, space, relativity, substance, and accident and their respective limits of use. Consequently, al-Māturīin asserts that the thesis of the thingness of nonexistence - which, for him, means to provide objects with truth value in pre-eternity ${ }^{35}$ contradicts the Qur'ānic approach that the "universe was taken from nothingness to existence through creation." On the other hand, the Mutazilah runs into a contradiction because of the view that attributes thingness to the nonexistent, similar to Thanawìi/Majūsī traditions that explain the universe by itself. ${ }^{36}$ Moreover, al-Māturīdī claims that the attribution of thingness to the nonexistent means accepting the pre-eternity of the universe and that this is because of ontological approaches that render divinity groundless.

According to al-Māturīdī, when considered together with this ontological approach, the Mu'tazili argument that the universe provides an indication of divinity becomes entirely meaningless. Indeed, divine knowledge about what is not yet existent but will eventually come into existence cannot be a cause that enables coming into existence. The same applies to eternality (al-qidam). ${ }^{37}$ In this respect, the theory of nonexistence apparently supports the defenders of the eternality of the universe. Indeed, according to the mentioned theory, the universe is supposed to be a self-creator (al$k h \bar{a} l i q)$ even though it is created. In other words, the universe has come into existence without a meta-entity and its creation. This

\footnotetext{
Al-Māturīdī, Kitāb al-tawhīd, 171.

35 Ibid., 151.

36 Ibid., $151 \mathrm{ff}$.

37 Ibid., 152
} 
presupposition paradoxically makes the universe the author of itself. Upon these determinations, al-Māturīdī proceeds to a dualist conception of the universe and makes certain comparisons. Accordingly, on the basis of the theory of attributes of actions, he states that the Mu'tazili attitude reduces Allah to the level of a created being. Indeed, pursuant to this Mu'tazili attitude, the category of attributes of actions cannot be ascribed to Allah as an attribute prior to actualization of the act. Once this view is approved, the ground for the becoming of the universe is the state of becoming that enables attaining the knowledge of becoming and comes after the indication of an act as dependent on it. ${ }^{38}$

Accordingly, in the eyes of al-Māturīdī, the argument adopted by the Mu'tazilī kalām scholar Muhammad ibn Shabīb, namely, "being is created by Allah out of nothing," has no meaning at all when it is considered together with the view that the "thingness of beings exists by themselves and not by Allah." Indeed, Ibn Shabīb's view of nonexistence contradicts creation out of nothing. Pursuant to the mentioned theory, it is not Allah who actually creates things; instead, Allah only brought into existence the essence ( $a l-d h \bar{a} t)$ of things out of nothing. In fact, they were things, albeit in nonexistence. For the question of why beings are created, the reply, "Beings are created for their aspects of interest," seems odd to al-Māturīdī. ${ }^{39}$ For him, it is unacceptable to think the mentioned objects are created for "interest/benefit" even though there is no being around to make use of them. Al-Māturīdī ironically says that this perspective befits the Mu'tazilah. Indeed, according to the Mu'tazili approach, being is explained without direct reference to a meta-entity. ${ }^{40}$

38 Al-Māturīì̄, Kitāb al-tawhīd, 153.

39 On one occasion, al-Māturīdī seems to support this oddness with the explicitness of wisdom: "Value accompanies creation. Blessings are explicit. Evidence of generosity are apparent. They comprise wisdom. The authority and proofs of will are certain. The sign of its power and traces of its knowledge are explicit. Therefore, it is useless to ask why. It is a peccable and improper question unacceptable to intellect." See al-Māturīì̄, Kitāb al-tawhìd, 235.

40 Ibid., 195. 


\section{From Meta-Entity to Meta-Value}

Discussions about the metaphysics of value in kalām are based on perspectives of reasoning and being in itself. ${ }^{41}$ These two concepts provide two opposite poles or references for legitimacy and validity within discussions of divinity. The first one considers and justifies being, knowledge, and value within a sequence of causes. ${ }^{42}$ This leads to a methodology that explains, justifies, and founds divinity not in itself but through its correlation with something outside it (good, evil, necessity, will, cause, motive, etc.). The second, in turn, particularly comprehends the realm of divinity and the metaphysics of value as a realm of being in itself. Pursuant to this determination, divinity is an origin that makes everything exist independently of external correlations and is sufficient to explain it and the metaphysics of value by itself. ${ }^{43}$

41 One of the earliest mentions of the concept of "being in itself" (al-inniyyab) appears in one of the tracts by the Zaydī kalām scholar al-Qāsim ibn Ibrāhīm alRassī (AH 169-246). In this tract called al-Dalìl al-kabìr, he uses al-inniyyah as he defines the quiddity of nonexistence. Furthermore, in his tract called Munāzarah ma'a l-mulhid, the expression inniyyat al-Sănic is employed in a criticism against him. Both terms are used in ontological context and do not share the context of value metaphysics as employed by al-Māturīiñ. See Abū Muḥammad al-Qāsim ibn Ibrāhīm al-Rassī, Majmū' kutub wa-rasā’il al-Imām alQāsim ibn Ibrābìm al-Rassī, 169-246 H, ed. 'Abd al-Karīm Aḥmad Jadbān (Ṣan'ā’): Dār al-Ḥikmah al-Yamaniyyah, 2001), 202, 294.

42 Ibn Sīnā indicates that in metaphysics, the question why/what for (li-ma) should be conclusively grounded on essence $(a l-d h \bar{a} t)$. This means that a thing is unconditional (li-dhātihì) for itself. See Abū 'Alī al-Husayn ibn 'Abd Allāh ibn 'Alī Ibn Sīnā, al-Shifā': al-Ilāhiyyāt (2), ed. George Anawati and Sa'īd Zāyed (Cairo: al-Hay’ah al-‘̄̄mmah li-Shu’ūn al-Mațābi` al-Amīriyyah, 1960), 298. Such views by Ibn Sīnā and al-Māturīdī are also observable in 'Ishrūn maqālah by Dāwūd ibn Marwān al-Muqammaș, a prominent figure of Jewish theology in $9^{\text {th }}$-century Baghdad, about the problem of the unity of divinity. In the relevant chapter, alMuqammaș emphasizes that the problem should be explained by means of reasoning. See Abū Sulaymān Dāwūd ibn Marwān al-Muqammaș, Twenty Chapters, ed. and trans. Sarah Stroumsa (Provo, Utah: Brigham Young University Press, 2015), Article I/clause 11.

43 In consideration of al-Māturīdì, the most appropriate abstract of this view is in Ta'dìl al-'ulum by the significant scholar Șadr al-sharīah, who reveals the 
Pursuant to the first, divinity is justified within the reasonability of intellect and morality, whereas the second completely prohibits reasoning from divinity. This is a necessary judgment not only in terms of being but also in terms of value. This complete prohibition of reasoning from divinity is essentially based on the perfection and competency of this realm. In fact, these two opposite points of view have become a point of origin that characterizes religious thought and establishes comprehensions of value. In the final analysis, the discussion in Islamic jurisprudence ( $a l$-fiqb) about whether religious provisions can be subject to ta' $\bar{\imath} l$, as well as kalām-related discussions on the relation between being and value and binding provisions of religion, are based on these two opposite principles. In this regard, the notion of reasoning enables the development of the Mu'tazili $\overline{1}$ theory of divinity and value based on an ethical foundation, ${ }^{44}$ whereas the notion of al-inniyyab transforms into a theory of divinity and value in two different manners, which are based on divine will and divine knowledge, respectively. Both forms of the notion of al-inniyyah have tilted to subjectivism because of the perception of transcendence-absoluteness; in both perspectives, the value is explained in reference to divine authority in the conclusive sense. Salafī and Ash'arī circles have refrained from causation as much as they can in regard to divinity since they are based on divine will. The one that is based on divine knowledge considers divinity by itself. Al-Māturīdì can be seen as the pioneer of this approach. This view, which frees the legitimacy and rationality of religious premises from dogmatism, has mostly emerged as a justification of al-inniyyah against reasoning in the criticism of Mu'tazilah by al-Māturīdì.

inniyyah-based approach as follows in his definition of the value metaphysics of divinity: 'لأنّه تعالى فاعل الخير، ولم يحصل من فعله صفة الكمال؛ بل حصل الفعل من صفة الكمال (The Almighty God is the author of all good. His attribute of perfection does not originate from his act. On the contrary, His act originates from his attribute of perfection)." See Șadr al-sharī‘ah al-thānī 'Ubayd Allāh ibn Mas'ūd ibn Tāj alsharī'ah 'Umar al-Maḥbūbī al-Hanafī, Sharḅ̣ Ta'dīl al-'ulūm fì l-kalām (MS Istanbul: Süleymaniye Library, Antalya Tekelioğlu, no.798), fol. 198 .

44 Despite significant differences arising from the distinction between Basrah and Baghdad, the Mu'tazilah agrees about the necessity of grounding on founding ethical judgments such as good, evil, necessity, justice, and absurdity, in the determination of the value content of divinity. 
According to al-Māturīdī, the universe does not have a single meaning, such as harm, benefit, evil (al-khabith), good (al-tayyib), blessing (al-ni'mab), or damnation (al-bala $\left.{ }^{\prime}\right)$. Therefore, each thing can have the quality of a value in one sense and another quality of value in another sense. In the universe, we cannot talk about benefit in any case or harm in any case. ${ }^{45}$ This is proof that the different and opposite existence of things cannot be explained without a metaentity (al-ghayr). In Māturīdī terminology, the meta-entity is a category that dismisses contrast and similitude. Any other possibility will both remove the otherness between things and put the metaentity in the category of being of the universe, a category based on form, similitude, difference, and contrast. ${ }^{46}$

For al-Māturīdī, deprivation of an entity from value is absurd; he indicates that man is self-sufficient ${ }^{47}$ in terms of intellectual capacity and value comprehension and cites divine commandments as a law of incentive and refrainment towards human nature in compliance with this capacity. Determining the content of value, he grounds his argument on principles of benefit-harm, like the Mu'tazilah of Basra, ${ }^{48}$ but he differs from the Mu'tazilah of Baghdad by accepting the coexistence of benefit-harm in the universe as divine wisdom in compliance with the nature of man as a tried being. ${ }^{49}$ Nevertheless, al-Māturīdī puts forth his meta-value approach by means of an

\section{Al-Māturīì̄, Kitāb al-tawhìd, 88.}

46 Ibid., 89.

47 According to the author, this competence is divided into two in terms of the cognitive capacity of the intellect. The first is the unchanging knowledge of intellect - justice, persecution, gratitude, and lie. The second is judgments of intellect within the unity of consequence (al-cāqibab), beginning (almuqaddimah), and state (al-hạal). See ibid., 272-274.

48 This view, which is expressed through the concepts of al-taklif, al-mashaqqah, al-kulfah and al-imtiḥān, is also observable in al-Qāsim ibn Ibrāhīm al-Rassī, Abū l-Qāsim al-Balkhī, al-Qāḍ̄ 'Abd al-Jabbār, and al-Jāhiz. See al-Rassī, Majmūc kutub wa-rasā'il, 310; al-Balkhī, Kitāb al-maqālāt, 213; al-Qāọī 'Abd al-Jabbār, al-Mughnī, XI, 294-295; Abū 'Uthmān 'Amr ibn Baḥr al-Jāḥiẓ, Kitāb al-ḥayawān, ed. 'Abd al-Salām Muḥammad Hārūn, $2^{\text {nd }}$ ed. (Cairo: Maṭba'at Muṣṭafá al-Bābī alHalabī, 1965), I, 204-207.

49 Al-Māturīì̄, Kitāb al-tawhìd, 167. 
inniyyah-based approach ${ }^{50}$ borrowed from philosophical terminology ${ }^{51}$ in the wake of his abovementioned cosmological views. This context enables participation in debates about the purpose/cause of the creation of the universe, where man is a member as well; in fact, these debates bring al-Māturīdī even closer to a theory of value.

As emphasized above, al-Māturīdī presents his point of view through criticism of others. The first one is explicit, whereas the second is implicit. His explicit criticism is against the Mu'tazili attitude that establishes divinity through an indication of intellect and morality; his implicit criticism is against the Salafí ' $u l a m \bar{a}^{\prime}$ and the Ash'ari circles, who treat divinity on the basis of divine will and power. Apparently, al-Māturīin tries to overcome the paradoxes arising from the divinity conceptions of these two attitudes by means of metaphysics of value and an approach based on being in itself. ${ }^{52}$ For him, the Mu'tazili approach clearly contradicts the transcendence

50 Two elements make al-Māturīdī's approach inniyyah-based. First, abandonment of wisdom renders Allah the possessor of ignorance; second, the same condition puts Allah into the status of a being with requirements (al-hajjah) (p. 296). This point of view is observable in his following striking statements: "The attribution of wisdom, justice, virtue, and beneficence is necessary. Indeed, Allah is Who knows (all) and Who is perfect” (p. 297); “... Allah cannot be thought in need or ignorant. In such case, His lordship is shaken and His sovereignty disappears" (p. 299).

51 According to Ibn Sinnā, Allah, Who is the First (al-awwal), is a being without parts, differentia, limits, evidence, cause (al-cillab), or why (li-ma) and whose act has no why (li-ma) (Ibn Sinnā, al-Shifá'? al-Ilābiyyāt (2), 348). Indeed, He is the origin of all things. He is the being Who is followed by nothing (Ibid., 354). He is the pure good. Good, in all aspects, is what everything wills for itself. Existence is purely good and purely perfect (Ibid., 355). Evil has no essence. Good is categorically willed by everything. It is what complements being. Evil means the absence of substance or its unrighteous situation (Ibid., 355). The perfection of being lies in the goodness of the being. Each perfection has a being. He is also the good that is not contaminated with evil and incompleteness in this regard (Ibid., 356).

52 The point is the impossibility of thinking about absoluteness and transcendence together undergoing the determination (power) of another principle. Al-Māturīiñ articulates this situation, which limits divinity, with the expression "stipulation in the sense of condition." See al-Māturīdī, Kitāb al-tawhīd, 164. 
of divinity; it is unacceptable since it attributes necessity to Allah and carries both intellect and morality beyond their respective ontological and epistemic limits, in other words, to the realm of transcendence. The Salafī 'ulam $\bar{a}$ ' and the Ash'arīs explained divinity exclusively through power and will. This explanation broke away the relation between Allah and value and made divinity arbitrary. Given this unity, al-Māturīīi initially aims at the Mu'tazilī approach that incorporates divinity within the realm of intellect and morality; for him, it is embarrassing to pose the question "why" to divinity and therefore to inquire why the universe is created in the beginning. ${ }^{53}$ Such an explanation expresses a point of view that is grounded on the transcendence of divinity against the perspective of reasoning and that considers divinity as something beyond intellect and morality but not in opposition (irrational) to them.

In this regard, al-Māturīdī aims at the essentialist and absolutist ethical approach of the Mu'tazilah of Baghdad and asserts that each condition, foreseen for the best, can also be mentioned for depravity $($ al-fas $\bar{a} d)$. As such, this perspective means refusing ontic comprehension of moral value judgments and the thesis that immobilizes the dynamic relation between existence and value. In addition, the author notes that the attitude that restricts divine will to the best is groundless. For him, whatever is foreseen for the best can also be mentioned for al-fasād. According to him, this arises from the fallacy that an "act without cause is unreasonable:"

... one who commits useless deeds is not considered to have acted on wisdom. Whoever acts without cause has busied himself with the unreasonable. Accordingly, some (of the Mu'tazilah of Baghdad) supposed that it is impossible for Allah to commit a deed which would harm anybody - under the conviction that it would remove wisdom. Therefore, they thought it was necessary for Allah to do the best in terms of religion and consequence for others. Indeed, He is free from any act that benefits or harms Himself. His acts can only be explained by

53 According to al-Māturīdī, this question is equivalent to questions such as why Allah is potent or why He is Who knows. See Kitāb al-tawhīd, 164. 
providing others with benefit or dismissing harm from such persons. This is also the (essential) cause of His acts... ${ }^{54}$

As the foregoing quotation shows, al-Māturīin noticed that the paradox arising from attributing cause to divinity is a consequence of constructing the value of divine creation and will on moral comprehension. This objection may have two motives: first, it is defined through something other than itself; second, the justification in definition can be employed for both positive and negative value. Pursuant to both perspectives, the author concludes that intellect and morality cannot apprehend divinity as grasping because of their limitedness and that they cannot employ their respective epistemes as references for this realm. Therefore, the relation between being and value can be exclusively explained on the basis of divine knowledge. Apparently, this was the point of departure for al-Māturīdī on his way to the principle of wisdom, the focal point of his thought. This is observable in his definition of wisdom as "flawless accuracy." "It is the involving and competent quality of divine knowledge that ensures flawless accuracy for being and existence. Therefore, value is not a quality in which being is imminent; instead, it is a wisdom of knowledge of Allah, a wisdom that is manifested in being. In other words, the act/will/creation of Allah bears the value of wisdom not because of an ethical reason but because His knowledge comprises perfection and absoluteness that does not allow for life and deficiency. Given this arbitrariness of divinity, we have no grounds to ask Him why.

Al-Māturīdī materializes his theoretical framework and aims at theory of the best. ${ }^{56}$ For him, this theory cannot be considered

54 Al-Māturīdī, Kitāb al-tawhìd, 295.

55 Clarifying the relation between wisdom and flawless accuracy, al-Māturīìi describes wisdom as to know the nonempirical by means of comprehension, knowledge, and the known; thus, he determines knowledge as the essential quality required for wisdom. See al-Māturīdī, Ta'wīlāt al-Qur'ān, XI (al-Qașaș Saba'), ed. Ali Haydar Ulusoy (Istanbul: Dār al-Mīzān, 2008), 227; VIII (al-Hijir al-Isrā’), ed. Halil İbrahim Kaçar (Istanbul: Dār al-Mīzān, 2006), 277. Also see Mahmut Ay, "Kelam'da Adalet, Kudret ve Hikmet Bağlamında Tanrı Tasavvurları," Eskiyeni 31 (2015), 43.

56 Al-Balkhī, Kitāb al-maqālāt, 230, 325-326. In the pages to which we refer, alBalkhī explains wisdom through fundamental ethical judgments such as good, 
together with divinity. Indeed, intellect and ethics cannot comprehend metaphysics based on divine knowledge and wisdom and cannot be used as a reference to explain the beginning of creation since both intellect and ethics are limited. This theory contradicts the transcendence of divinity. In this context, the author asserts that the existence of things, which are negated in the theory of the best and which cause harm and deprivation to the living excluded from Allah, is grounded on two wisdoms. The first is that man is tried by the harm and benefit to emerge, even though intellect cannot grasp it. ${ }^{57}$ The taste of al-thawāb for the appreciation of obedience to religion and the grief of punishment imposed for disobedience can only be possible on this equivalence based on trial. In the theory of the best, the negative situations leading to all harms and deprivations that are naturally excluded from the being and Allah seem to have attained, thanks to the approach of al-Māturīdì, a theological content that holds together benefit and harm in compliance with the possible acts and consequences of human nature. ${ }^{58}$ The author tries to provide this content by means of the will of Allah to construct an envisagement within human consciousness of reward and punishment (al-thawāb - al-iqāb) on the basis of the concrete (al$\left.a^{\prime} y \bar{a} n\right)$. This attitude shares the Mu'tazili concern as it ascribes to all living and nonliving things a content of value in compliance with the phenomenon of religion that is binding on man. According to alMāturīdī, however, the second wisdom behind bringing into existence/creation of things that cause harm and deprivation is that they gain the capacity to bear difficulties in all their diversity. Such competence (al-tahammul) can only be realized through rational inquiry/contemplation (al-nazar/al-tafakkur), albeit at varying levels. Indeed, man does not gain any advantage in practice for using his intellect (al-nazar/al-fikr). On the contrary, this use keeps him

evil, benefit, and harm. This is the very point al-Māturīdì contests. He associates wisdom with divine knowledge; therefore, he stands for transcendence and thus being in itself instead of ethics.

Al-Māturīìi, Kitāb al-tawhìd, 176.

58 Al-Māturīdī explains the point as follows, aiming at the categorical distinction in Thanawi theology: "Allah created beings in two manners, namely, which do harm and which do good. He rendered each substance susceptible for grief and taste. This determination arises from its consequences. This manner makes man avoid one and head for the other." See ibid., 249. 
away from taste and lust, whose value of interest is clear and strong. Even though it is hard to endure the difficulty of contemplation, which deprives man of interest, its negligence paves the way for dispute and discord. Once the difficulty in using the intellect is overcome, the avoidance of harm and orientation towards benefit, which are equivalent, attain an epistemological ground. ${ }^{59}$ According to al-Māturīdī, this epistemological ground functions in such manner to facilitate repetition during childhood; it provides man with sufficient conditions of being subject to religion. ${ }^{60}$

Al-Māturīìi attributes all of existence to Allah without any separation between its aspects of harm and benefit. This approach is based on a teleological perspective that, in the final analysis, exceeds intellect and morality through divine knowledge and that does not see any differences between the qualities of value in things such as benefit-harm or good-evil. Indeed, each existence has wisdom pursuant to the flawlessly accurate quality of divine knowledge, regardless of the quality or consequence of things. ${ }^{61}$ Therefore, all value judgments, including good and evil, provide proof of the unity, knowledge, and wisdom of Allah, like a single substance. This emphasis by al-Māturīin can be understood as a response to the categorical distinction by dualist theology of the indication between both value judgments. Therefore, regardless of their value judgment, they provide the value of a common proof for the universe in terms of testimony and indication. ${ }^{62}$ For him, the oppositions of benefitharm and good-evil within things is a method to assure discipline for cruel persons who apply violence and power and to make them understand their actual powerlessness; in addition, these oppositions are proof of the power, perfection, and transcendence of the creator. Therefore, divine deeds with these qualities are exempt from benefiting and being harmed in themselves. ${ }^{63}$ For al-Māturīiñ, the value qualities of things, albeit opposite, are based on divine wisdom foreseen for man; therefore, he refuses the Mu'tazili view that attributes only the good to Allah and exempts Him from any kind of

\footnotetext{
59 Al-Māturīì̄, Kitāb al-tawḥ̂̀d, 175.

60 Ibid., 176.

61 Ibid., 193

62 Ibid., 176.

63 Ibid.
} 
evil. Indeed, the opposition between benefit and harm and good and evil is equivalent in relation to divine knowledge that exceeds the limits of the indication of intellect. Therefore, it is impossible to make a distinction of comparison and exclusion on the basis of the opposition of benefit-harm and good-evil within the limits of intellect; moreover, this cannot be transformed into a theory of value for divination.

Al-Māturīin criticizes the absolutist approach of the Mu'tazilah of Baghdad for determining the value quality of things in an essential manner; in this respect, he notes that a thing may be of a quiddity that can be described as both good and evil and that harmful things may coexist with benefits that cannot be appropriately comprehended. ${ }^{64}$ For instance, water has a value that ensures life for every living thing but may also cause extinction of the living. Each thing with a quality of harm also comprises a benefit that constitutes a basis for an opposite assertion about it. Therefore, good and evil are not two distinct substances, as alleged by the Muctazilah of Baghdad. Instead, good and evil are those for which each substance may provide origin. Al-Māturīin therefore indicates that the presence of two opposite aspects within things is one of the most sublime/greatest proofs of divinity. ${ }^{65}$ For him, this situation is an indication of complete might on harm and benefit; it is also the origin of two aspects of astonishment, one positive and one negative, which lead man to be in hope and worry. Accordingly, al-Māturīin concludes that the authority of commandment, which is binding on man, cannot be considered without the competence of Allah, Who allows the coexistence of two opposite-value qualities within things. Otherwise, we have to claim the incompetence of Allah. Moreover, in such cases, man would not have desire and concern, which would lead to human tendencies of commitment and avoidance. Therefore, in the eyes of al-Māturīdì, the formation of the comprehension of object lessons defined in the Qur'ān by means of the universe depends on the coexistence of the qualities of benefit and harm. ${ }^{66}$

Al-Māturīdī criticizes the method of Muhammad ibn Shabīb, who replies to the question of why a thing does not come into existence at

\footnotetext{
64 Al-Māturīì̄, Kitāb al-tawhìd, 176.

65 Ibid.

66 Ibid.
} 
any time other than the time at which it does with the imminent situation of the thing and eliminates all other possibilities. ${ }^{67}$ Accordingly, al-Māturīdī contests him asking why existence occurs by means of a cause not within but outside itself. In reply, Muhammad ibn Shabīb apparently establishes the context also to be condemned by al-Māturīdī: since a thing comes into existence by means of what is outside it, such becoming must have an interest (al-mașlaḥah) with regard to religion and world. This does not apply for the meta-entity (al-ghayr) and the existence of the nonexistent. ${ }^{68}$ Al-Māturīi apparently lays the foundation of debate through the reply by Muhammad ibn Shabīb to Dahriyyah. The author constructs his argument on the anachronism caused by the principle of interest adopted by his respondent. The anachronism here is between the interest and the fact that the first created thing is an untried being (not subject to divine proposal). Otherwise, the realization of first creation by means of a different possibility will wipe away interest. According to al-Māturīdī, the words by Muhammad ibn Shabīb in this context do not really mean much. Indeed, the question of why and the quest for causation in the realm of divinity contradict the being in itself and transcendence of divinity. Indeed, the realization of a deed under these circumstances renders the meta-entity subject to criticism. ${ }^{69}$ Nevertheless, the meta-entity is a being whose deed/creation never goes out of wisdom. ${ }^{70}$ The fact that it does/creates what is best for another living or nonliving thing does not mean evaluation of a deed in itself. On the contrary, this means asserting that the thing

${ }_{67}$ Al-Māturīìi, Kitāb al-tawhì̄, 191.

68 Ibid.

69 Ibid., 192.

70 The effort by al-Māturīiñ to take divinity towards epistemic ground is clearly observable in Ibn Sīnā, who explains wisdom through knowledge in a similar manner. Wisdom, as al-Māturīì̄ says, is considered in an epistemic comprehension and defined as the utmost (al-afdal) certainty and the maximum knowledge (on another occasion, Ibn Sinna clarifies the maximum good [al-afdal] by corresponding it with the concept of certainty [al-yaqin]). In other words, wisdom is the most correct and most perfect knowledge (al-ma'rifah); it is the universal knowledge of the original causes. Calling it "the first philosophy," Ibn Sīnā describes this realm as absolute wisdom. For him, wisdom is the universal knowledge of final (al-qușwâ) causes. See Ibn Sīnā, al-Shifầ': al-Ilāhiyyāt (2), 5, 15. 
done/created is necessary ( $w \bar{a} j i b)$ for the meta-entity. However, it is impossible to talk about the emergence of any right/necessity ${ }^{71}$ with regard to a meta-entity when there is nothing but it.

\section{Conclusion}

In terms of divinity, al-Māturīdī seems to acknowledge al-Muhāsibī regarding the incompetence/inability of intellect; accordingly, alMāturīdī admits that intellect, which is the origin of value judgments such as good-evil and justice, is a faculty that cannot surpass its limits $(m a h d \bar{u} d)$. In his eyes, limitedness has a strategic function to justify the argument that in terms of inability and incompetence, the intellect cannot be the founding principle of value in there (divinity) as in here (physics). This attitude enables al-Māturīdī to assert that moral judgments of intellect are competent within the limits of physics but that it is impossible to reach the realm of divinity (as the Muctazilah did) through the same judgments. In other words, the (ethical) value capacity of intellect does not/cannot precede the creator and the creation in the establishment of metaphysics of value. Such a limitation seems compliant within ontological and epistemological divisions that exist between humans and the divine and that arise from differences of quiddity. This perspective substantially differs from not only the Mu'tazilah but also the Salafīs and the Ash'arīs, who stress power and will, since al-Māturīdī constructs his envisagement of divinity on divine knowledge and not on divine power and will. Even though it is based on an epistemic comprehension, this change of paradigm sides with a perspective that shares the purposes and concerns of ethics-based Mu'tazili value theory and that avoids the arbitrariness of the legitimacy of divinity since it does not condition the latter on will and power. As a result, al-Māturīīis principle of wisdom is a logical consequence of divine knowledge, which is flawless and perfect in everything and which, accordingly, requires flawless accuracy. This point of view not only deconstructs the Salafi and Ash'ari envisagement of divinity but is also an effort to exceed

71 In this case, it is meaningless to say "Allah creates man for His interest and benefit." Indeed, it is impossible to talk about harm and decay about things not created for themselves (with regard to those yet to be created). Al-Māturīdī, Kitāb al-tawhìd, 192. 
the Mu'tazili envisagement that weakens the transcendence of divinity on the grounds of a moral code of intellect.

This perspective is developed earlier than Ibn Sinnā's, who builds divinity on the principle of being in itself. Unlike other approaches to divinity, al-Māturīì maintains the unity of realms of being, knowledge, and value. Thus, he is able to develop an epistemological perspective that does not ascribe necessity to Allah and does not contradict moral code. The distinguishing feature of his theory is that he understands the metaphysics of value in a manner that comprises two (intellectual and moral) modes from the realm of divinity down to human reality. Accordingly, intellect and morals, within their limitedness, mean two forms/possibilities of valuation for the realization of divine wisdom in the human realm as a value-related quality of divine knowledge. These two forms, which we call realization (al-tahaqquq), are defined by al-Māturīdī as justice and virtue. Virtue cannot be considered limited given the transcendence and perfection of divinity; on the contrary, it incorporates endless possibilities with regard to Allah. Therefore, no best manner of virtue can be in question despite allegations of the theory of the best. In addition, within the scope of criticism about the doctrine of the best of the Mu'tazilah of Baghdad, virtue and justice cannot be considered necessary in any manner whatsoever because of the transcendence of divinity as well as moral comprehension. The same applies for justice. Justice is not constant or uniform and comprises an indication with various degrees. This is a result of the impossibility of thinking of transcendence and limitedness together. Therefore, pursuant to theory based on being in itself, the value bears a relationality from outside to inside - in other words, from the divine to the human. Divine knowledge in its transcendent, that is, unlimited, state is the point of origin for value and is based on wisdom that involves all value judgments before and after creation. In this context, wisdom has a function that does not reduce ontological contrast to absurdity and cannot ensure the transitivity of value between the creator and the created. Indeed, the created existence means the realization of wisdom as justice and virtue in line with its own ontology and limitedness. Two cognitive forms of wisdom limited to the universe, namely, justice and virtue, are not sufficient to move from here to the context where only the meta-entity exists. Indeed, since this context is based on divine knowledge, it includes endless possibilities beyond the limits of justice and virtue of the intellect. 


\section{DISCLOSURE STATEMENT}

No potential conflict of interest was reported by the author.

\section{BIBLIOGRAPHY}

al-Ash'arī, Abū 1-Ḥasan 'Alī ibn Ismācî̀. Maqālāt al-Islämiyyìn wa-khtiläf almuṣallīn. Edited by Aḥmad Jād. Cairo: Dār al-Hadìth, 2009.

Aslan, İbrahim. Kâdî Abdülcebbâr'a Göre Dinin Aklî ve Ablâkî Savunusu. Ankara: OTTO, 2014.

—. "İmam Maturidî̀nin Deist Eleştirilere Karşı Nübüvvet Savunusu.” Kelâm Arastırmalar 12, no. 2 (2014): 33-54. https://doi.org/10.18317/kader.03592.

Ay, Mahmut. "Kelam'da Adalet, Kudret ve Hikmet Bağlamında Tanrı Tasavvurları." Eskiyeni 31 (2015): 25-50.

al-Baghdādī, Abū Manșūr 'Abd al-Qāhir ibn Țāhir. Al-Farq bayna l-firaq wa-bayān al-firqah al-näjiyah minhum: 'Aqā'id al-firaq al-Islämiyyah wa-ärā' kibār a lāmihāa. Edited by Muhammad 'Uthmān al-Khusht. Cairo: Maktabat Ibn Sīnā, 1988.

al-Balkhī, Abū l-Qāsim 'Abd Allāh ibn Aḥmad. Kitāb al-maqālāt wa-ma'ahū 'Uyūn al-masā'il wa-l-jawābāt. Edited by Hüseyin Hansu, Rājị Kurdī, and 'Abd alHamīd Kurdī. Istanbul: KURAMER, 2018.

Ibn Sīnā, Abū 'Alī al-Ḥusayn ibn 'Abd Allāh ibn 'Alī. al-Shifāà: al-Ilāhiyyāt (2). Edited by George Anawati and Sa'īd Zāyed. Cairo: al-Hay’ah al-‘Āmmah li-Shu’ūn alMațābic al-Amīriyyah, 1960.

al-Jāḥiz, Abū 'Uthmān 'Amr ibn Baḥr. Kitāb al-ḥayawān. Edited by 'Abd al-Salām Muhammad Hārūn. $2^{\text {nd }}$ ed. 8 vols. Cairo: Maṭba'at Muștafá al-Bābī al-Halabī, 1965.

al-Khayyāṭ, Abū l-Ḥusayn 'Abd al-Rahīm ibn Muhammad. Kitāb al-intișār wa-l-radd calá Ibn al-Rāwandī al-mulhid mā qașada bih̀̃ min al-kadhib calá $l$ Muslimin wa-l-ta'n 'alaybim. Edited by H. Samuel Nyberg. Cairo: Mațba'at Dār al-Kutub al-Mișriyyah, 1925.

al-Māturīīi, Abū Manșūr Muḥammad ibn Muḥammad ibn Maḥmūd. Kitāb al-tawhìd. Edited by Bekir Topaloğlu-Muhammed Aruçi. Beirut \& Istanbul: Dār Ṣādir \& ÍSAM Yayınları, 2007.

—. Ta'wìlāt al-Qur'ān, VIII (al-Hijr - al-Isrā'). Edited by Halil İbrahim Kaçar. Istanbul: Dār al-Mīzān, 2006.

—. Ta'wīlät al-Qur'ān, XI (al-Qașaș - Saba'). Edited by Ali Haydar Ulusoy. Istanbul: Dār al-Mīzān, 2008.

al-Muqammaș, Abū Sulaymān Dāwūd ibn Marwān. Twenty Chapters. Edited and translated by Sarah Stroumsa. Provo, Utah: Brigham Young University Press, 2015. 
al-Najrānī, Taqī al-Dīn Muhhtār ibn Maḥmūd al-'Ujālī. al-Kāmil fì l-istiqșā' fìmā balaghanā min kalām al-qudamā'. Edited by Sayyid Muḥammad al-Shāhid. Cairo: Wizārat al-Awqāf, 1999.

al-Qāẹī 'Abd al-Jabbār, Abū l-Hasan 'Abd al-Jabbār ibn Aḥmad al-Hamadānī. Faḍl ali'tizāl wa-țabaqāt al-Mu'tazilah. Edited by Fu'ād Sayyid. In Faḍl al-i'tizāl wa-țabaqāt al-Mu'tazilah, along with Abū 1-Qāsim al-Balkhī's (Bāb) Dhikr al-Mu'tazilab min Maqālāt al-Islāmiyyìn and Hākim al-Jishumī's alTabaqatān al-ḥādiyah 'ashrah wa-l-thāniyah 'ashrah min kitāb Sharh al'uyūn. Tunis: al-Dār al-Tūnisiyyah li-l-Nashr, 1974.

al-Mughnī fì abwāb al-tawhìd wa-l-'adl, V (al-Firaq ghayr al-Islāmiyyah). Edited by Maḥmūd Muḥammad Qāsim. Cairo: al-Dār al-Miṣriyyah li-l-Ta’lîf wa-l-Tarjamah, n.d.

. al-Mughnī, VI/1 (al-Ta'dīl wa-l-tajwìr). Edited by Aḥmad Fu’ād al-Ahwānī (Cairo: al-Mu’assasah al-Mișriyyah al-Āmmah li-1-Ta'liff wa-l-Tarjamah wa-1Tibā'ah wa-l-Nashr, 1962.

. al-Mughnī, VII (Khalq al-Qur’ān). Edited by Ibrāhīm al-Abyārī. Cairo: alSharīkah al-'Arabiyyah li-1-Tibā'ah wa-1-Nashr, 1961.

. al-Mughnī, XI (al-Taklīf). Edited by M. 'Alī al-Najjār and 'Abd al-Halīm alNajjār. Cairo: al-Dār al-Mișriyyah li-l-Ta'līf wa-l-Tarjamah, 1965.

. al-Mughnī, XII (al-Nazar wa-l-ma'ārif). Edited by Ibrāhīm Madkūr. Cairo: al-Mu'assasah al-Mișriyyah al-‘̄̄mmah li-1-Ta'lif wa-l-Tarjamah wa-l-Ṭibā'ah wa-l-Nashr, n.d.

- al-Mughnī, XIV (al-Aṣlaḥ, istiḥqāq al-dhamm, al-tawbah). Edited by Mușțafá al-Saqqā. Cairo: al-Dār al-Mișriyyah li-l-Ta’liff wa-l-Tarjamah, 1965.

al-Rassī, Abū Muhammad al-Qāsim ibn Ibrāhīm. Majmū' kutub wa-rasā’il al-Imām al-Qāsim ibn Ibrāhìm al-Rassī, 169-246 H. Edited by 'Abd al-Karīm Aḥmad Jadbān. Ṣan‘ā’’: Dār al-Hikmah al-Yamaniyyah, 2001.

Rudolph, Ulrich. Al-Mãturìdì and the Development of Sunnī Theology in Samarqand. Translated by Rodrigo Adem. Leiden \& Boston: Brill, 2015. https://doi.org/10.1163/9789004261846.

Ṣadr al-sharī'ah al-thānī, 'Ubayd Allāh ibn Mas'ūd ibn Tāj al-sharī'ah 'Umar alMaḥbūbī al-Ḥanafī. Sharḥ Ta'dīl al-‘ulūm fì l-kalām. MS Istanbul: Süleymaniye Library, Antalya Tekelioğlu, no.798.

al-Shahrastān̄i, Abū l-Fatḥ Tāj al-Dīn Muhammad ibn 'Abd al-Karīm. Al-Milal wa-lniḥal. Edited by Aḥmad Fahmī Muḥammad. 3 vols. in 1. Beirut: Dār al-Kutub al-'Tlmiyyah, 1990. 